\title{
Tropical tele-connections to the Mediterranean climate and weather
}

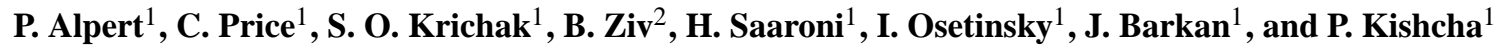 \\ ${ }^{1}$ Tel Aviv University, Tel Aviv, Israel \\ ${ }^{2}$ The Open University of Israel, Tel Aviv, Israel
}

Received: 24 October 2004 - Revised: 31 January 2005 - Accepted: 2 February 2005 - Published: 13 May 2005

\begin{abstract}
Some strong natural fluctuations of climate in the Eastern Mediterranean (EM) region are shown to be connected to the major tropical systems. Potential relations between EM rainfall extremes to tropical systems, e.g. El Niño, Indian Monsoon and hurricanes, are demonstrated. For a specific event, high resolution modelling of the severe flood on 3-5 December 2001 in Israel suggests a relation to hurricane Olga. In order to understand the factors governing the EM climate variability in the summer season, the relationship between extreme summer temperatures and the Indian Monsoon was examined. Other tropical factors like the Red-Sea Trough system and the Saharan dust are also likely to contribute to the EM climate variability.
\end{abstract}

\section{Introduction}

The Mediterranean climate is likely to be affected by several tropical systems as illustrated by some evidence collected in this paper. These factors range from the El Niño Southern Oscillation (ENSO) and tropical hurricanes to the Indian Monsoon and even to Saharan dust. This could lead to complex features in the Mediterranean climate variability. In the following sections we review some tropical teleconnections to the Mediterranean climate in the following order: El-Niño (Sect. 2), tropical cyclones (Sect. 3), Indian monsoon (Sect. 4), Sudanese Low - Red Sea Convergence Zone extending toward the Eastern Mediterranean as a Red Sea Trough (Sect. 5); and Saharan dust (Sect. 6). A special focus is given to the Central and Eastern Mediterranean.

\section{EI Niño and rainfall in Israel and Italy}

The El Niño-Southern Oscillation (ENSO) is the largest oscillation of the Earth's climate system after the annual cycle, lasting for 12-18 months each time it occurs. Anomalies

Correspondence to: P. Alpert

(pinhas@cyclone.tau.ac.il) in tropical Pacific SST and pressure, peaking in December (during the Mediterranean winter rainy season), lead to shifts in global circulation patterns, which may result in changes in circulation patterns in midlatitudes, even in the Mediterranean.

We have investigated the possible teleconnection between the tropical Pacific temperature anomalies and rainfall in northern Israel (Price et al., 1998). It was found that a highly significant statistical connection exists between winter SSTs in the central/eastern Pacific (Nov-Apr), and integrated rainfall in northern Israel (Fig. 1). Instead of using rainfall from only a few isolated stations, we used winter season Jordan River streamflow anomalies, an integrated rainfall index for the entire watershed. As shown by Price et al. (1998, their Fig. 1), there is no shift in time when seasonal averages of rainfall and Jordan River stream flow are concerned. Although a positive correlation exists, the strongest El Niño does not have the largest streamflow anomalies, and vice versa. However, 8 or 9 El Niño winters had above normal rainfall in northern Israel. We need to point out that this connection was not found in the data prior to the 1970s. Have the teleconnections changed over time? We explain these recent connections via changes in the position of the winter jet stream during ENSO years. The mean position of the jet stream in winter in the eastern Mediterranean is $30 \mathrm{~N}$, exactly the latitude of Israel. If the jet stream shifts equatorward (El Niño) or poleward (La Niña) by a few degrees, significant changes in precipitation amounts can occur.

Alpert et al. (2002) have also shown enhanced contributions of daily torrential rainfall in Italy during El-Niño years.

\section{Tropical Cyclones and rainfall in Israel}

Reale et al. (2001) showed that several cases of severe floods over the Western Mediterranean could be traced back to hurricanes. Also, Hoskins and Berrisford (1988) related the severe 1987 storm in South England to hurricanes. Next, we review a first study showing the relationship between Israel 


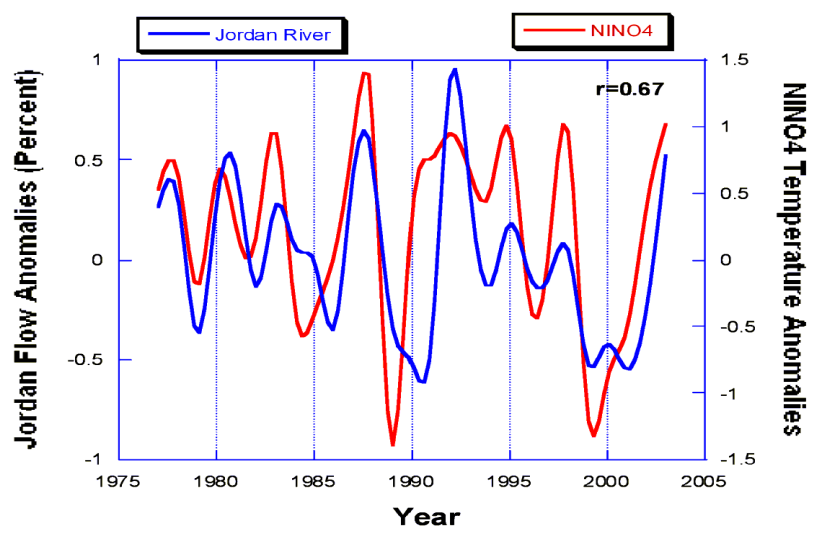

Fig. 1. The winter streamflow in the Jordan River and the winter Niño4 SSTs in the tropical Pacific. From Price et al. (1998).

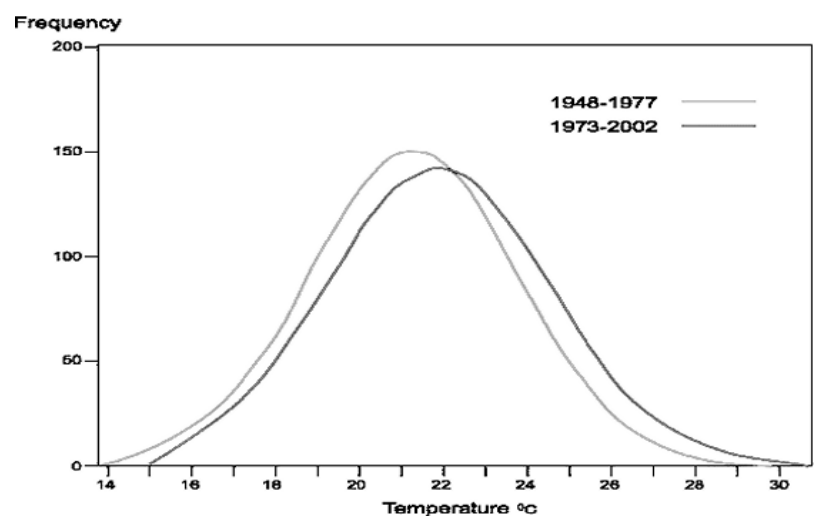

Fig. 2. Distribution of $850 \mathrm{hPa}$ daily temperatures at the $32.5 \mathrm{~N}$, $35 \mathrm{E}$ grid point for two 30-year periods: grey line: 1948-1977, black line: 1973-2002. The peak of each curve represents the mode temperature for the respective period. From Saaroni et al. (2003).

\section{Indian Monsoon and climate in the Eastern Mediter- ranean}

\subsection{Summer}

The climatic regime and the dynamic factors governing the EM in the summer season were analyzed. Two main dynamic factors, competing with each other, were found to affect the EM: Upper- to mid-level subsidence and lower-level cool Etesian winds, which counteract each other. The persistent subsidence, causing the rain absence over the EM during summer, was found to be linked to the Asian Monsoon via a closed circulation clearly seen in the isentropic cross-section (Ziv et al., 2004). It was found that strengthening (weakening) of the Asian Monsoon enhances (weakens) both competing dynamic factors over the EM, resulting in the annual minimum of inter-diurnal temperature variations (Saaroni et al. 2003). A long-term trend of the average seasonal temperatures over the EM indicates a warming trend of $0.013 \mathrm{~K} / \mathrm{y}$ (for the period 1948-2002). This warming was combined with an increase in the extremity of the temperature regime, manifested by an increase in the frequency of both "hot" and "cool" days and by an increase in the seasonal maximum temperatures, $0.020 \mathrm{~K} / \mathrm{y}$, which is three times larger than the increase in the respective minimum temperatures. Both trends are demonstrated by the temperature distribution for the two 30-year sub-periods (Fig. 2) (Saaroni et al., 2003). It is worth noting also that the warm spells have become longer with time.

\subsection{Winter}

It has been also recently shown (Alpert et al., 2004c) that winter rainfall in Israel in extreme seasons (since 1880) is in a significant negative correlation with the rainfall index for the preceding summer Indian Monsoon. 


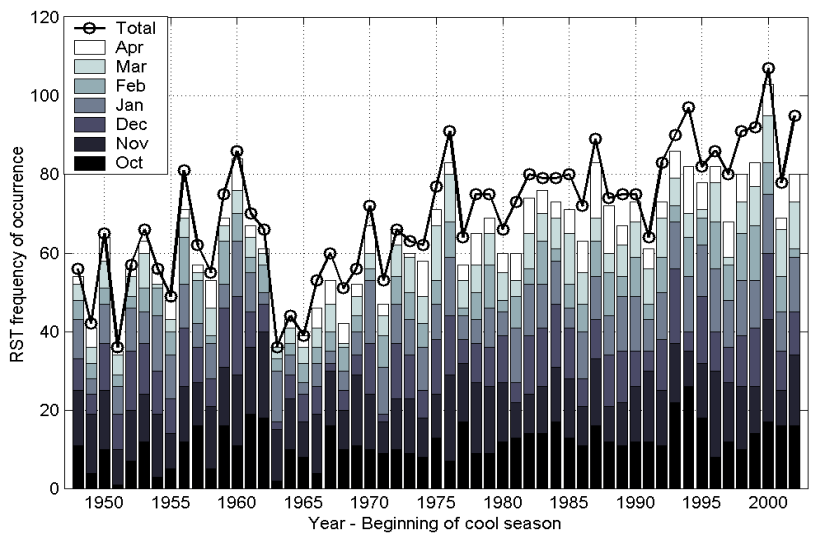

Fig. 3. The Red Sea Trough frequencies as totals per hydrological year (August to July) and cumulative monthly contributions (October to April).

\section{Red-Sea Trough's trends and EM climate}

The Red Sea Trough (RST) synoptic system develops over the EM region in the cool season (October to April), when the Subtropical High retreats southwestward out of the EM. The RST, which is characterized by the easterly winds in its north-eastern part, mostly brings dry weather into the EM countries, with large diurnal temperature variations. The semi-objective classification of the EM daily synoptic systems (Alpert et al., 2004a) allowed analyzing the climatic trend in the numbers of RST days (frequencies of occurrence). Since mid-1960s to early 2000s the annual numbers of the RST days rose from about 40 to about 100 (Fig. 3). This means a general drying of the EM climate. For instance, the drought of late 1950s - early 1960s over the EM corresponds to a local rise in RST frequencies. Alternatively, two recent remarkably rainy EM winters - 1991/92 and 2002/3 correspond to local drops in RST frequencies.

Averaged seasonal distributions of the RST frequencies during two 28-year adjacent non-overlapping periods have been analyzed on a daily basis following Alpert et al. (2004b). Comparison of these two periods for the month of October shows that the rise in the October RST frequencies (Fig. 3) was accompanied by the reductions in the Persian Trough (PT) frequencies in the first decade of this month and those of the Subtropical High (SH) in its second and third decades. Both PT and SH are the warm season's systems with westerly winds that bring the moisture of the Mediterranean Sea into the EM countries. At the same time, the increase of the October frequency of RST was accompanied by the decrease in the frequency of the Cyprus Lows bringing the rainfall in the region. Consequently, the October increase in RST frequencies explains the general drying EM climate in the early autumn, in spite of the fact of increasing number of the October rainfall in South Israel.

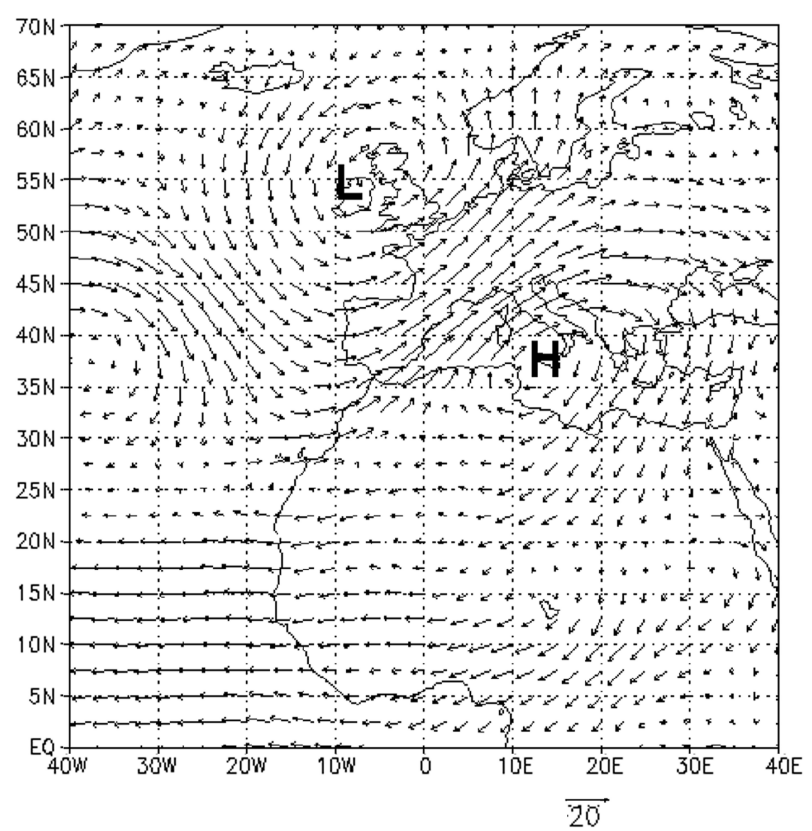

Fig. 4. Average wind flow of the dusty period 5-9 July 1988 at $700 \mathrm{hPa}$. From Barkan et al. (2005).

\section{Mediterranean dust transport from Sahara}

The role of atmospheric aerosols on the climate system is found to be most significant (IPCC, 2001). The mean synoptic situation associated with dust outbreaks from Sahara into the Central Mediterranean was examined on daily basis for the month of July from 1979 to 1992 (Barkan et al., 2005). It was found that the strength and position of two essential features of the circulation patterns, such as the trough emanating southward from the Iceland low and the eastern cell of the subtropical high, are the governing factors in making suitable flows for the Saharan dust transportation toward Central Europe. The typical composite pattern of wind in the case of five days of great quantity of dust in the atmosphere above Italy between 5-9 July 1988 is shown by Fig. 4. One can see a deep low over Ireland with a strong trough emanating from it southward and splitting the subtropical high into two separate cells. The eastern one is seen over Sicily. Between the Irish low and the Sicilian high, a strong southwesterly flow transports dust from Mauritania across the Western Mediterranean to Central Europe.

\section{Conclusions}

The aforementioned evidence of tropical tele-connections to the Mediterranean climate suggests further analysis in order to test these relationships by using appropriate statistical methodologies. 
Acknowledgements. This study was supported by the Israeli Science Foundation (ISF, grant no. 828/02) and also by the GLOWA-Jordan River BMBF-MOS project.

Edited by: L. Ferraris

Reviewed by: V. Pawlowsky-Glahn and another referee

\section{References}

Alpert, P., Ben-Gai, T., Baharad, A., Benjamini, Y., Yekutieli, D., Colacino, M., Diodato, L., Ramis, C., Homar, V., Romero, R., Michaelides, S., and Manes, A.: The paradoxial increase of Mediterranean extreme daily rainfall in spite of decrease in total values, Geophys. Res. Lett., 29, 11, 31-1-31-4, (June issue), 2002.

Alpert, P., Osetinsky, I., Ziv, B., and Shafir, H.: Semi-objective classification for daily synoptic systems: application to the eastern Mediterranean climate change, Int. J. Climatol., 24 (8), 10011011, 2004a.

Alpert, P., Osetinsky, I., Ziv, B., and Shafir, H.: A new seasons definition based on classified daily synoptic systems: an example for the eastern Mediterranean, Int. J. Climatol., 24 (8), 10131021, 2004b.

Alpert, P., Ilani, R., da-Silva, A., Rudack, A., and Mandel, M.: Seasonal prediction for Israel winter precipitation based on northern hemispheric EOF, MERCHAVIM special issue, in press, 2004c.
Barkan, J., Alpert, P., Kutiel, H., and Kishcha, P.: The synoptics of dust transportation days from Africa toward Italy and Central Europe, J. Geophys. Res., in press, 2005.

Hoskins, B. J. and Berrisford, P.: A potential vorticity perspective of the storm of 15-16 October 1987, Weather, 42, 122-129, 1988.

IPCC: Intergovernmental Panel on Climate Change, Climate Change 2001, The Scientific Basis (contribution of WG I to the 3rd Assessment Report of the IPCC), Cambridge University Press, Cambridge, 2001.

Krichak, S. O., Alpert, P., and Dayan, M.: The Role of atmospheric processes associated with hurricane Olga in the December 2001 floods in Israel, J. Hydrometeorology, 5, 1259-1270, 2004.

Price, C., Stone, L., Rajagopalan, B., and Alpert, P.: A possible link between El Nino and precipitation in Israel, Geophys. Res. Lett. 25, 3963-3966, 1998.

Reale, O., Feudale, L., and Turato, B.: Evaporative moisture sources during a sequence of floods in the Mediterranean region, Geophys. Res. Lett., 28, 2085-2088, 2001.

Saaroni, H., Ziv, B., and Alpert, P.:Long-term variations in the summer temperatures over the Eastern Mediterranean, Geophys. Res. Lett., 30 (18), 1946, doi:10.1029/2003GLO17742, 2003.

Ziv, B., Saaroni, H., and Alpert, P.: The factors governing the summer regime of the eastern Mediterranean, Int. J. Climatol., 24, 1859-1871, 2004. 